\title{
Corrigendum: Small genomic insertions form enhancers that misregulate oncogenes
}

\author{
Brian J. Abraham, Denes Hnisz, Abraham S. Weintraub, Nicholas Kwiatkowski, Charles H. Li, Zhaodong Li, \\ Nina Weichert-Leahey, Sunniyat Rahman, Yu Liu, Julia Etchin, Benshang Li, Shuhong Shen, Tong Ihn Lee, \\ Jinghui Zhang, A. Thomas Look, Marc R. Mansour \& Richard A. Young
}

Nature Communications 8:14385 doi: 10.1038/ncomms14385 (2017); Published 9 Feb 2017; Updated 1 Jun 2017

In the original version of Supplementary Data 1 associated with this Article, the list of predicted enhancer-associated insertions was inadvertently truncated. The HTML has now been updated to include the correct version of the Supplementary Data 1.

(c) Open Access This article is licensed under a Creative Commons Attribution 4.0 International License, which permits use, sharing, adaptation, distribution and reproduction in any medium or format, as long as you give appropriate credit to the original author(s) and the source, provide a link to the Creative Commons license, and indicate if changes were made. The images or other third party material in this article are included in the article's Creative Commons license, unless indicated otherwise in a credit line to the material. If material is not included in the article's Creative Commons license and your intended use is not permitted by statutory regulation or exceeds the permitted use, you will need to obtain permission directly from the copyright holder. To view a copy of this license, visit http://creativecommons.org/licenses/by/4.0/

(C) The Author(s) 2017 